\title{
Geoelectric Investigation for Groundwater Prospects in Ejeme-Aniogor and Environs, Aniocha- South Local Government Area, Delta State, Nigeria
}

\section{CHINYEM, FI}

\author{
Department of Geology, Faculty of Science, \\ Delta State University, P.M.B. 1, Abraka, Delta State \\ E-mail: fichinyem@gmail.com
}

\begin{abstract}
Geoelectric investigation for groundwater prospects in Ejeme-Aniogor and environs, Aniocha- South Local Government Area of Delta State, Nigeria was carried out with a view to determining the near subsurface lithologies and depths; as well as thickness of the various aquiferous zones/units in the study area. Fourteen vertical electrical soundings (VES) technique, employing the Schlumberger configuration were used in investigating the groundwater prospects, with maximum current electrode spacing of $500 \mathrm{~m}$. The acquired field data were interpreted quantitatively by partial curve matching and computer iteration. The result showed six to eight geoelectric layers with resistivities ranging from 120 to $1700 \Omega \mathrm{m}$ for the topmost layer and 276 to $163000 \Omega m$ for the bottommost layer. The result also revealed that the depths to the various aquiferous zones ranged from 28.5 to $162 \mathrm{~m}$ while the thickness of the aquiferous zones ranged from 20.3 to $58.7 \mathrm{~m}$. The aquiferous units in the study area were mostly confined and the results obtained from the study were found to be consistent with the lithologic logs obtained from borehole drilled in the study area. A generalized depth to the water table (acquiferous zones) cannot be deduced for the study area because it varied from one locality to another. However, the result showed that the area has good prospects for groundwater development. @JASEM

https://dx.doi.org/10.4314/jasem.v21i4.8
\end{abstract}

Keywords: Geoelectric investigation, groundwater prospects, Ejeme - Aniogor, aquiferous zones, groundwater development.

Water is health, water is wealth and water is life. Good drinking water can be obtained from rocks, but drilling without previous site investigations seldom yield water in useful quantities (Palacky et al., 1981). Effective water development programmes must include carefully conducted geological and geophysical investigations. Water is one of the essential necessities of nature indispensable to all organic life plant and animal development (Obioha and Nwachukwu, 2007). It occurs in springs, rivers, streams and lakes in surface basins, falls as rain and occurs in the subsurface in porous, permeable rocks formations as groundwater. The importance of groundwater as a supply source to the socioeconomic development of a country is very great. In this $21^{\text {st }}$ century, there is increasing demand for water supply for physical industrial development to achieve maximum human growth (Olasehinde, 2011). Groundwater is by far the most important source of drinking water in Nigeria (Goki, 2011). It is tapped through wells and bore holes in most urban and rural areas. Geo-electrical techniques are powerful tools and play a vital role in groundwater investigations particularly in the delineation of the aquifer configuration in geological environments (Olasehinde, 2011). A planned geo-electrical investigation is capable of mapping an aquifer system, clay layers, the depth and thickness of aquifers etc, and this has been adopted for in this study.
Investigation of depths to water tables in EjemeAniogor and environs is imperative because of rampant cases of boreholes with poor water yield, boreholes getting dried up soon after commission and sometimes outright abandonment even amongst those owned by the state government. This study is therefore aimed at investigating the near surface geologic formations in the area in view of groundwater development. It involved the use of vertical electrical sounding (VES) technique, employing Schlumberger electrode configuration at fourteen VES locations in Ejeme-Aniogor and environs. Borehole litho-logic log was incorporated into the interpretation to minimize discrepancies in deduced geo-electric parameters and that obtained from bore holes. It is hoped that the results of this investigation would be of immense importance in future groundwater development program in these areas, as it would provide information on probable depths to suitable aquiferous units.

The objective of this present study was to investigate the groundwater prospect in Ejeme - Aniogor and Environs, Aniocha South Local Government Area, Delta State, because of increasing demand for potable water by the inhabitants.

\section{MATERIALS AND METHODS}

Description of Study Area with Map and Location: The study area is located within longitude $6^{0} 17^{0}$ to 
$6^{0} 24^{0} \mathrm{E}$ of the Greenwich Meridian and latitude $6^{0} 00^{1}$ to $6^{0} 05^{1} \mathrm{~N}$ of the Equator and is accessible by major and minor roads. Ejeme - Aniogor and environs consists of semi-urban towns. The elevation of the area ranges from 55 to $102 \mathrm{~m}$ above sea level.The area is well drained by two rivers: River Adofi and River Omu. and the drainage pattern is basically dentritic. The drainage system is dominated by River Adofi which has its source at Ejeme-Aniogor and flows southwards towards Ossissa in Ndokwa- East Local Government Area of Delta State before it empties its water into the River Niger. The area falls within the localities where the lithofacies of the Niger Delta grade gradually into the lithofacies of the Anambra basin (Freeborn, 2006). It is underlain from the earth's surface by the Benin Formation, OgwashiAsaba Formation and Ameki Formation, with equivalent of Upper Agbada Formation (Reyment,
1965). The geology of the Niger Delta has been described extensively by Allen (1965); Burke et al., (1972) Short and Stauble (1967) and Murat (1970). It consists basically of three diachronous stratigraphic units viz: the Benin, Agbada and Akata Formations. The Benin Formation is dominantly a fluvial facies unit made up of $90 \%$ sand/sandstone and clay intercalations. The age ranges from Oligocene to recent (Reyment, 1965). The Agbada formation is a Deltaic facies unit made up of an alternating sequence (sandstone - shale). This sequence is in response to eustatic changes in sea level during sedimentation. The age ranges from Eocene to Recent. The Akata Formation is an open marine faces (pro-delta) unit dominated by under pressured shale of 2000 to $4000 \mathrm{~m}$ in thickness. The age ranges from Paleocene to Recent (Reyment, 1965).

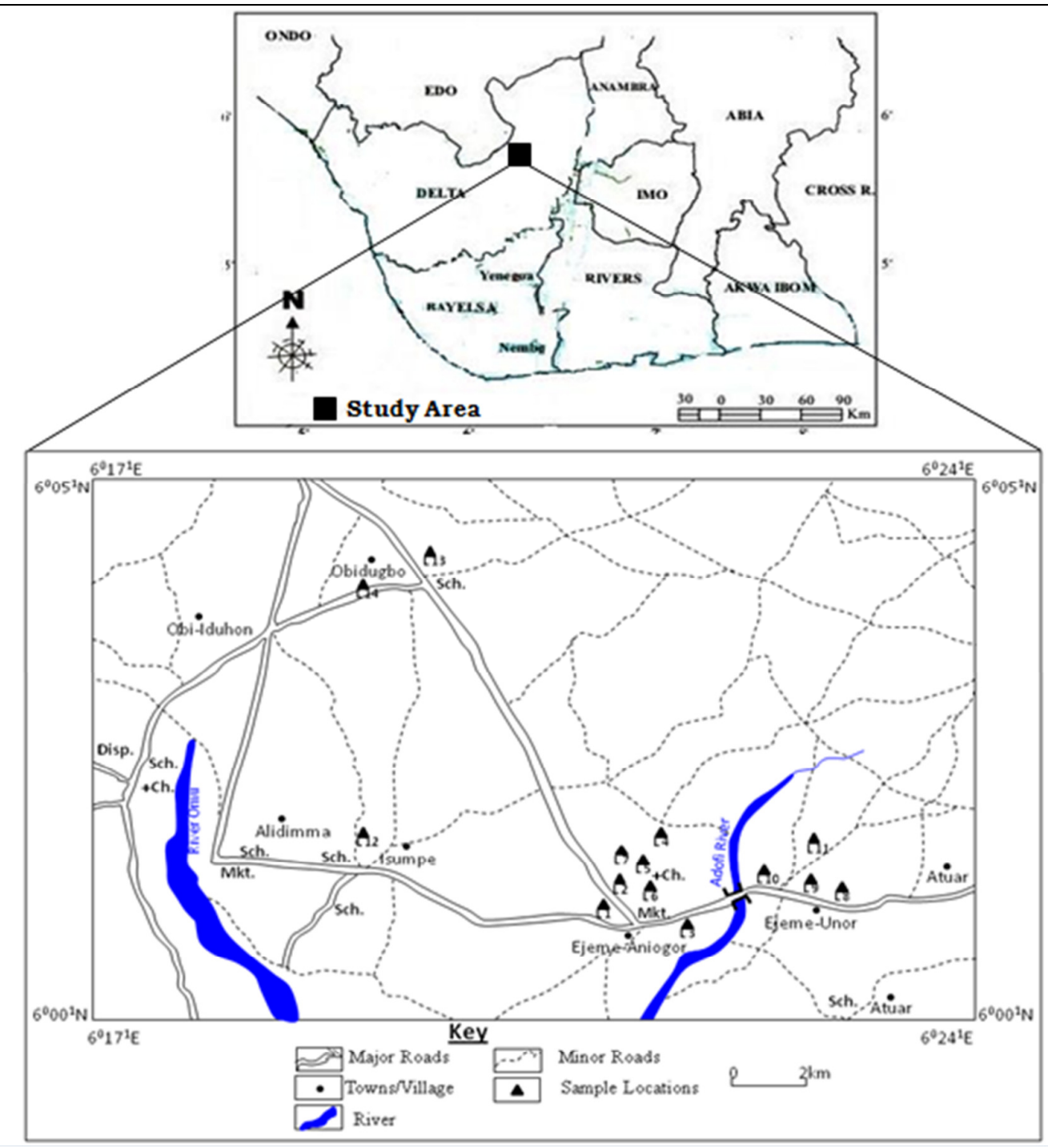

Fig 1: Map of Niger Delta Showing the Location of Study Area 
Data Sampling: The electrical resistivity data were acquired using the ABEM Signal Averaging System (SAS) 1000 Terrameter Resistivity meter. The survey involved 1-D Vertical Electrical Sounding (VES) and the VES utilized the Schlumberger electrode array with half - current electrode separation $(\mathrm{AB} / 2)$ that ranged from 1 to $500 \mathrm{~m}$ depending on accessibility. A total of fourteen VES stations were occupied (Figure 1). The coordinates of each VES station were taken with the Garmin Global Positioning System (GPS) equipment to ensure correct future geo - referencing.

Data Processing and Data Interpretation: The observed field data were used to produce depth sounding curves. The Signal Averaging System (SAS 1000) Terrameter Resistivity Meter, which was used for data acquisition could compute and display the apparent resistivity of the subsurface layer with the input data of the electrode configuration, the current and potential electrode separation (Chinyem 2013). The VES data presented as depth sounding curves (Figures 2 and 3) were inverted with the aid of computer aided iteration curve matching techniques. The apparent resistivity obtained was plotted on a log - log graph paper with the electrode separation $(\mathrm{AB} / 2)$ on the abscissa and apparent resistivity $\left(\rho_{\mathrm{a}}\right)$ values as the ordinate. The thickness and resistivity values obtained from the partial curve matching were then used for a quantitative computer iteration using the Schlumberger O' Neil software package (Schlumberger, 1986). Thus, the iterated geoelectric parameters were used to generate geo - electric sections (Figures 5 and 6) for the study area. The geologic interpretation of the VES results was aided by the litho- logic log of a borehole drilled in the area by the Delta State Ministry of water Resources (DSMWR; 2010), Asaba (Figure 4).

\section{RESULTS AND DISCUSSION}

The results of the investigation are presented, sounding curves and geo-electric sections (Figures 2 and 3). Figures 5 and 6 show the geo-electric sections of the study area.

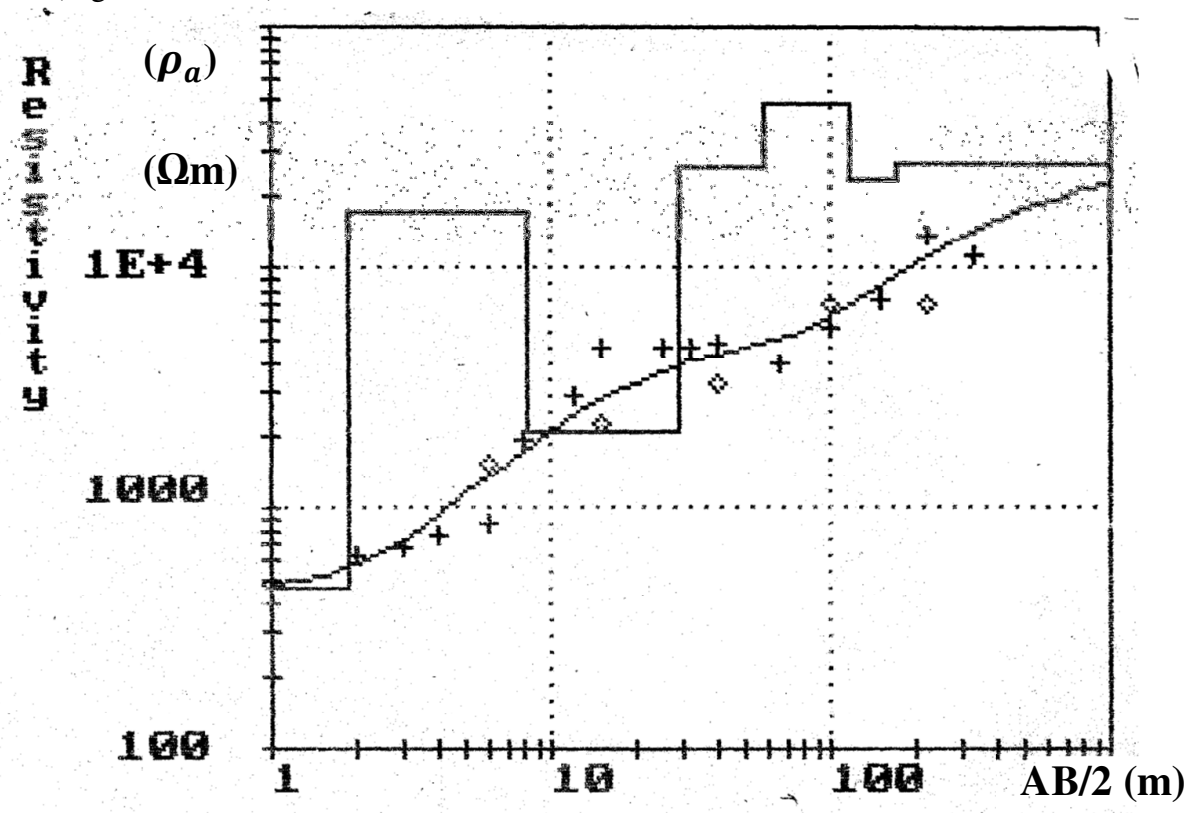

Fig 2: Typical Sounding Curve for Ejeme-Aniogor and Environs (VES 1) 


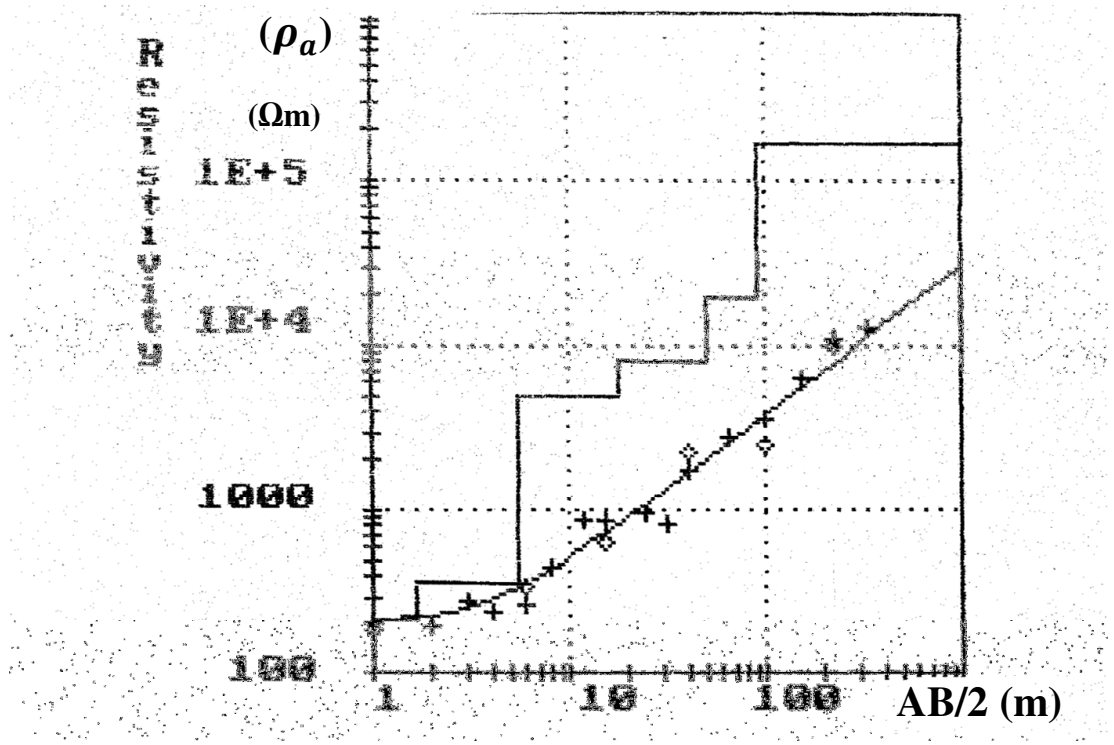

Fig 3: Typical Sounding Curve for Ejeme-Aniogor and Environs (VES 9)

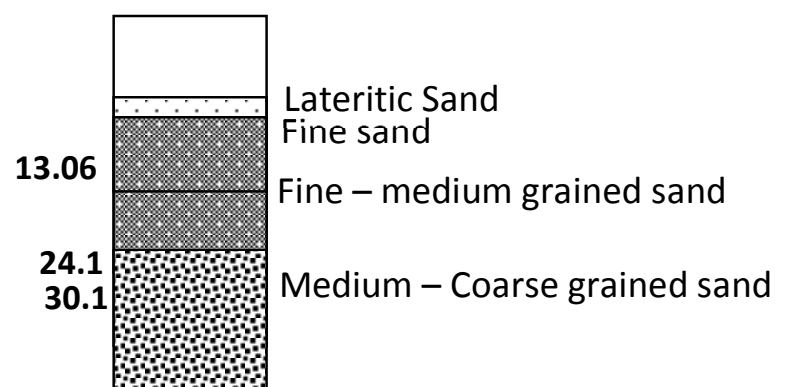

Fig 4: Borehole lithologic log at Ejeme - Aniogor.

(Courtesy: Delta State Ministry of Water Resources (DSMWR), 2010) 


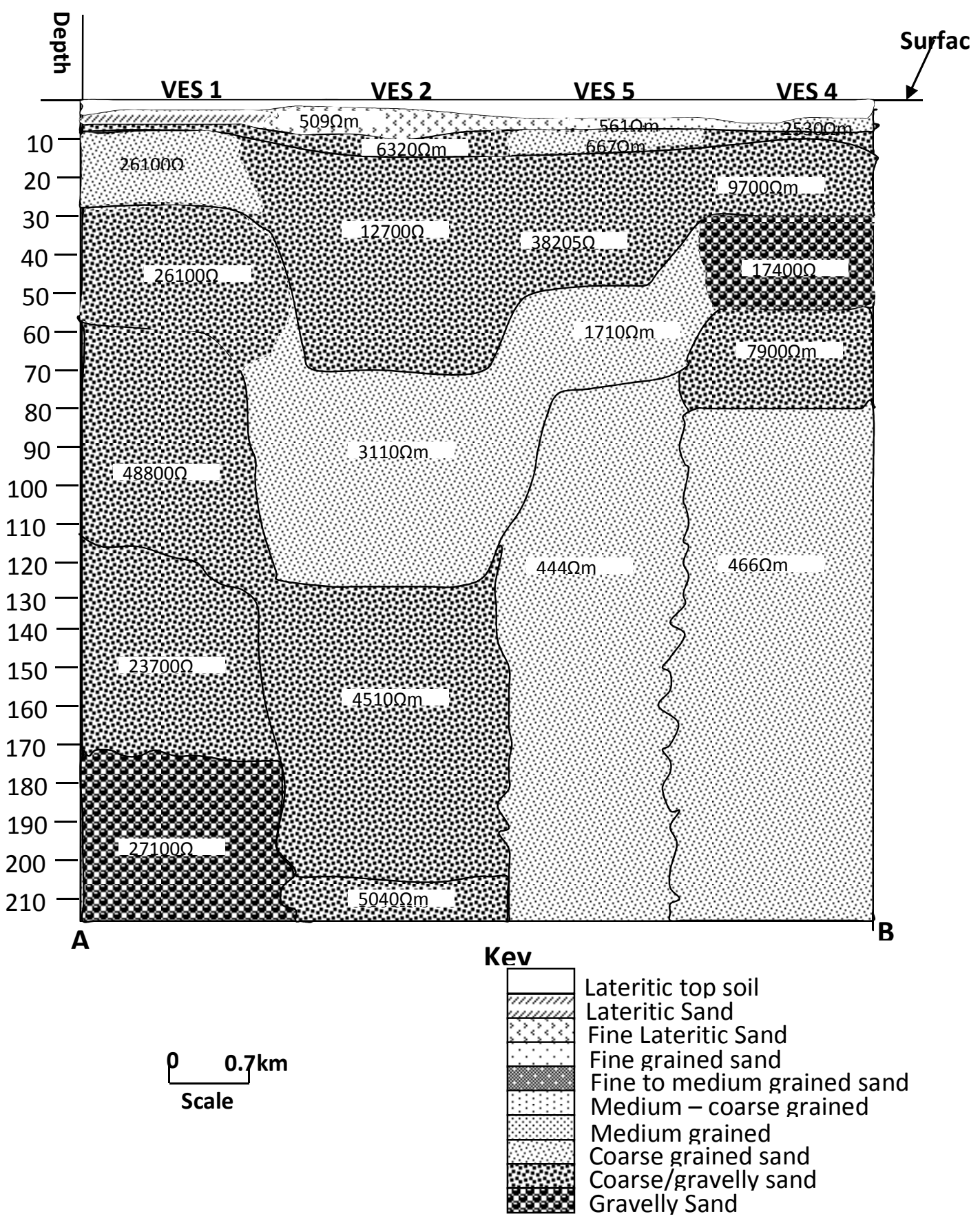

Fig 5: Geoelectric section of the VES results (VES 1,2,4 and 5) 


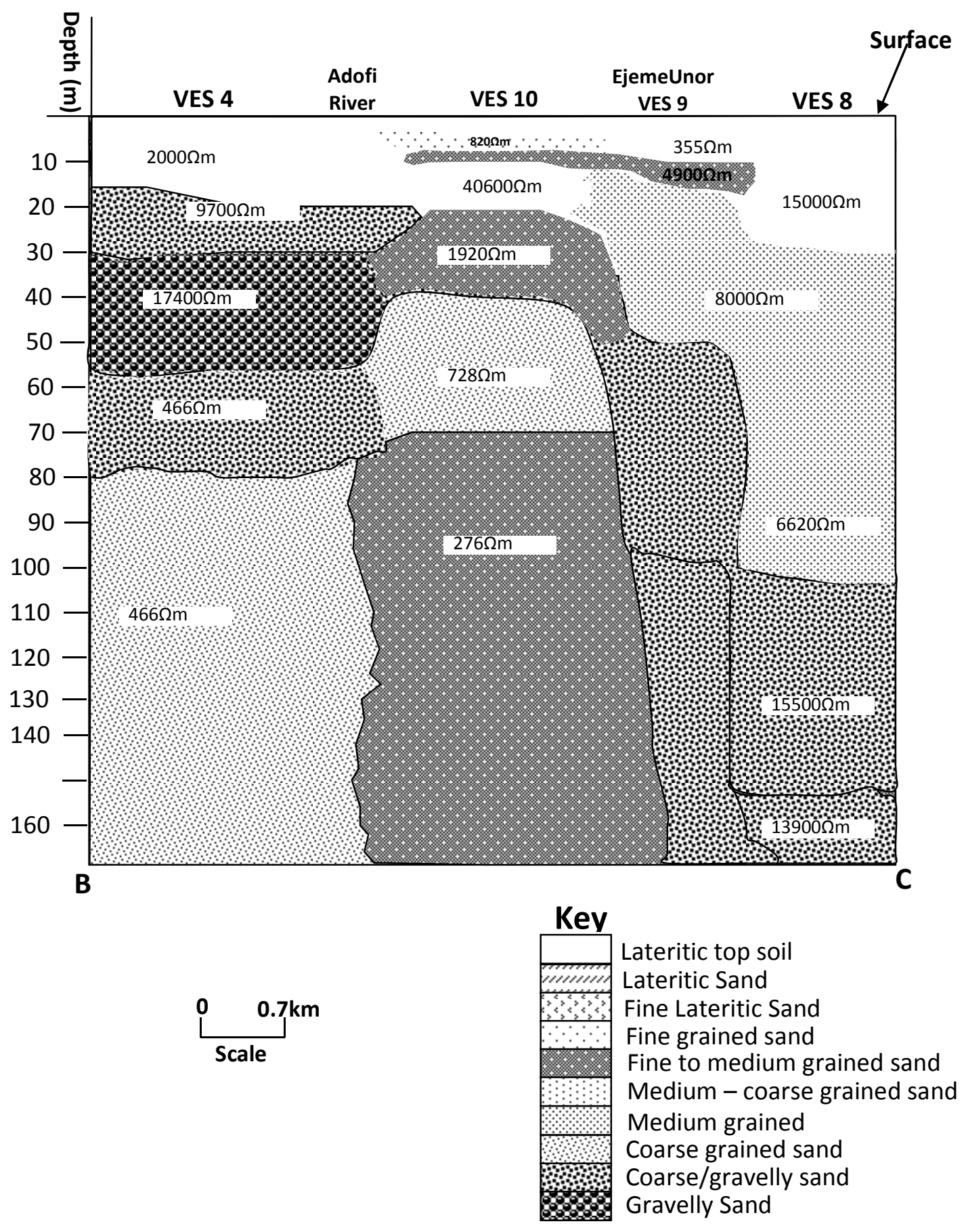

Fig 6: Geoelectric Section of the VES results (VES 4,8,9,10)

VES 1 location (Market Square, Ejeme -Aniogor; Latitude $06^{0} 00^{1} 50.83^{11} \mathrm{~N}$; Longitude $06^{0} 21^{1} 12.20^{11} \mathrm{E}$ )is made up of eight layers with resistivities that ranged from 460 to $48800 \Omega \mathrm{m}$, depth ranging from 0.8 to $172 \mathrm{~m}$. This location has an altitude of $62 \mathrm{~m}$. The lithologies inferred include: lateritic top soil for the first layer; lateritic sand for the second layer; fine lateritic sand for the third layer; medium to coarse grained sand for the fourth layer; coarse grained sand for the fifth layer; coarse/gravelly sand for the sixth layer; coarse grained sand for the seventh layer and gravelly sand for the eight layer. The aquiferous unit delineated lies within layer 4 with resistivity of $2050 \Omega \mathrm{m}$, depth and thickness of $28.5 \mathrm{~m}$ and $20.3 \mathrm{~m}$ respectively. 
VES 2 location (Along Obidugbo road, EjemeAniogor; latitude $06^{0} 00^{1} 54.34{ }^{11} \mathrm{~N}$; longitude $06^{0} 21^{1} 13.36^{11} \mathrm{E}$ ) is made up of seven layers with resistivity values that ranged from 206 to $12700 \Omega \mathrm{m}$ and depth ranging from 0.6 to $205 \mathrm{~m}$. VES 2 location has an altitude of $73 \mathrm{~m}$. The lithologies inferred include: lateritic top soil for the first layer; fine lateritic sand for the second layer; coarse grained sand for the third layer; coarse/gravelly sand for the fourth layer; medium-coarse grained sand for the fifth layer; coarse grained sand for the sixth layer and coarse grained sand for the seventh layer. The aquiferous unitlzone delineated lies within layer five with resistivity of $3110 \Omega \mathrm{m}$, depth and thickness of $127 \mathrm{~m}$ and $58.7 \mathrm{~m}$ respectively.

VES 3 location (Aniogor Primary School, Ejeme Aniogor; latitude $06^{0} 00^{1} 54.98^{11} \mathrm{~N}$; longitude $06^{0} 21^{1} 33.54^{11} \mathrm{E}$ ) is made up of six layers with resistivity values which ranged from 555 to 25800 $\Omega \mathrm{m}$ and depth range from 0.8 to $117 \mathrm{~m}$. This location has an altitude of $70 \mathrm{~m}$. The deduced lithologies include: lateritic top soil for the first layer; fine lateritic sand for the second layer; medium grained sand for the third layer; coarse grained sand for the fourth layer; medium-coarse grained sand for the fifth layer and coarse/gravelly sand for the sixth layer. The aquiferous unit delineated lies within the fifth layer with resistivity value of $1240 \Omega \mathrm{m}$, depth and thickness of $117 \mathrm{~m}$ and $75 \mathrm{~m}$ respectively. This location is regarded as potential aquiferous unit, hence better boreholes drilled at that depth will have good water yield.

VES 4 location (Ejeme Secondary School, EjemeAniogor; latitude $06^{0} 01^{1} 32.56^{11} \mathrm{~N}$; longitude $06^{0} 21^{1} 25.71^{11} \mathrm{E}$ ) is made of sevenlayers with resistivity values that ranged from 259to $17400 \Omega \mathrm{m}$ and depth from 0.9 to $77.5 \mathrm{~m}$. The altitude of this location is $76 \mathrm{~m}$. The deduced lithologies includes: lateritic top soil for the first layer; fine-medium grained sand for the second layer; coarse grained sand for the third layer; coarse/gravelly sand for the fourth layer; gravelly sand for the fifth layer; coarse/gravelly sand for the sixth layer and medium-coarse grained sand for the seventh layer. The aquiferous unit lies within the third layer (first aquifer) with resistivity of $2000 \Omega \mathrm{m}$, depth and thickness of $17.4 \mathrm{~m}$ and $12.7 \mathrm{~m}$ respectively and also in the sixth layer (second aquifer) with resistivity value of $7900 \Omega \mathrm{m}$, depth and thickness of $77.5 \mathrm{~m}$ and $23.4 \mathrm{~m}$ respectively.

VES 5 location (Ogbe-Unor Quarters, EjemeAniogor, latitude $05^{0} 01^{1} 07.37^{11} \mathrm{~N}$; longitude $06^{0} 21^{1} 19.70^{11} \mathrm{E}$ ) is made up of six layers with resistivity values that ranged from 166 to $3820 \Omega \mathrm{m}$ and depth from 0.7 to $75.2 \mathrm{~m}$. This location has an altitude of $72 \mathrm{~m}$. The deduced lithologies include: lateritic top soil for the first layer; fine grained sand for the second layer; fine to medium grained sand for the third layer; coarse grained sand for the fourth layer; medium to coarse grained sand for the fifth layer and medium grained sand for sixth layer. The aquiferous unit lies within the fifth layer with resistivity of $1710 \Omega \mathrm{m}$, depth and thickness of $75.2 \mathrm{~m}$ and $26.2 \mathrm{~m}$ respectively.

VES 6 location (Umu-Agolo Quarters, Ejeme Aniogor; latitude $06^{0} 01^{1} 00.09^{11} \mathrm{~N}$; longitude $06^{0} 21^{1} 24.28^{11} \mathrm{E}$ ) is made up of six layers with resistivity that ranged from 120 to $138000 \Omega \mathrm{m}$ and depth ranging from 0.4 to $46.6 \mathrm{~m}$. The altitude of this location is $69 \mathrm{~m}$. The deduced lithologies include: lateritic top soil for the first layer; lateritic sand for the second layer; coarse grained sand for the third layer;course/gravel sand for the fourth layer; coarse grained sand for the fifth layer and coarse grained sand for the sixth layer.The aquiferous unit delineated lies within fifth layer with resistivity of $33000 \Omega \mathrm{m}$ with depth and thickness of $46.6 \mathrm{~m}$ and $24.5 \mathrm{~m}$ respectively.

VES 7 location (Obelese Quarters, Ejeme - Aniogor; latitude $06^{0} 01^{1} 00.45^{11} \mathrm{~N}$; longitude $06^{0} 21^{1} 24.87^{11} \mathrm{E}$ ) consists of six layers with resistivity values which ranged from 131 to $1740 \Omega \mathrm{m}$, depth range from 0.6 to $98.4 \mathrm{~m}$. This VES location has an altitude of $68 \mathrm{~m}$. The deduced lithologies include: lateritic top soil for the first layer, fine-medium grained sand for the second layer, coarse grained sand for the third layer, medium to coarse grained sand for the fourth layer, coarse grained sand for the fifth layer and mediumcoarse grained sand for the sixth layer. The deduced aquiferous unit lies within fourth layer with resistivity of $1690 \Omega \mathrm{m}$, depth and thickness of $63.7 \mathrm{~m}$ and $24.1 \mathrm{~m}$ respectively.

VES 8 location (Police station, Ejeme - Unor; latitude $06^{0} 01^{1} 50.74^{11} \mathrm{~N}$; longitude $06^{0} 22^{1} 41.00^{11} \mathrm{E}$ ) is made up of six layers with resistivity values that ranged from 820 to $139000 \Omega \mathrm{m}$ and depth range from 1.9 to $148 \mathrm{~m}$. The altitude of this location is $71 \mathrm{~m}$. The deduced lithologies include: lateritic top soil for the first layer; fine to medium grained sand for the second layer; coarse grained sand for the third layer; medium to coarse grained sand for the fourth layer; coarse/gravelly sand for the fifth layer and coarse/gravelly sand for the sixth layer. The aquiferous unit lies within the fourth layer with resistivity of $6620 \Omega \mathrm{m}$, depth and thickness of $97 \mathrm{~m}$ and $67.7 \mathrm{~m}$ respectively. This location is regarded as potential aquiferous zone and borehole drilled at this depth will have good water yield.

VES 9 location (Adofi Primary School, Ejeme-Unor; latitude $06^{0} 01^{1} 09.54^{11} \mathrm{~N}$; longitude $06^{0} 22^{1} 25.53^{11} \mathrm{E}$ ) is made up of six layers with resistivity that ranged from 212 to $163000 \Omega \mathrm{m}$, and depth range from 1.7 to $90.2 \mathrm{~m}$. This location has an altitude of $66 \mathrm{~m}$. The deduced lithologies include: lateritic top soil for the 
first layer; fine to medium grained sand for the second layer; medium grained sand for the third layer; medium grained sand for the third layer; medium-coarse grained sand for the fourth layer;coarse/gravelly sand for fifth and sixth layers respectively. The prospective aquiferous unit lies within the fourth layer with resistivity value of 8000 $\Omega \mathrm{m}$, depth and thickness of $50.4 \mathrm{~m}$ and $32.4 \mathrm{~m}$ respectively.

VES 10 location (Obi's Palace, Ejeme - Unor; latitude $06^{0} 01^{1} 08.71^{11} \mathrm{~N}$; longitude $06^{0} 22^{1} 22.92^{11} \mathrm{E}$ ) comprises seven layers with resistivity values that ranged from 422to $40600 \Omega \mathrm{m}$ and depth from 1.2 to $72.4 \mathrm{~m}$. The altitude of this location is $55 \mathrm{~m}$. The deduced lithologies include: lateritic top soil for the first layer; fine grained sand for the second layer; medium to coarse grained sand for the third layer; coarse/gravelly sand for the fourth layer; medium coarse grained sand for the fifth layer; medium grained sand for the sixth layer and fine to medium grained sand for the seventh layer. The potential aquiferous unitllayer delineated lies within the fifth layer with resistivity of $1920 \Omega$ m,depth and thickness of $41.6 \mathrm{~m}$ and $77.5 \mathrm{~m}$ respectively.

VES 11 location (Umusam Quarters, Ejeme-Unor; latitude $06^{0} 00^{1} 52.70^{11} \mathrm{~N}$; longitude $06^{0} 22^{1} 19.05^{11} \mathrm{E}$ ) consists of seven layers with resistivity values which ranged from 653to $88000 \Omega \mathrm{m}$ and depth range from 1.2 to $130 \mathrm{~m}$. The altitude of this location is $63 \mathrm{~m}$. The deduced lithlogies include: lateritic top soil for the first layer; fine to medium grained sand for the second layer; coarse grained sand for the third and fourth layers respectively; coarse grained sand for the fourth layer; coarse/gravelly sand for the fifth and sixth layers respectively. The aquiferous unit lies within the sixth layer with resistivity value of 36200 $\Omega \mathrm{m}$, depth and thickness of $130 \mathrm{~m}$ and $58 \mathrm{~m}$ respectively.

VES 12 location (Ulogwe - Isumpe; latitude $06^{0} 01^{1} 18.02^{11} \mathrm{~N}$; longitude $06^{0} 18^{1} 59.75^{11} \mathrm{E}$ ) is made up of seven layers with resistivity values that ranged from 217 to $29800 \Omega \mathrm{m}$ and depth range from 0.9 to $206 \mathrm{~m}$. This location has an altitude of $102 \mathrm{~m}$. The deduced lithologies include: lateritic top soil for the first layer; fine grained sand for the second layer; fine to medium grained sand for third layer; coarse/gravelly sand for the fourth layer; medium coarse grained sand for the fifth layer; coarse/gravelly sand for the sixth layer and coarse grained sand for the seventh layer. The potential aquiferous zone delineated lies within the fifth layer with resistivity value of $4050 \Omega \mathrm{m}$, depth and thickness of $141 \mathrm{~m}$ and $42.6 \mathrm{~m}$ respectively.

VES 13 location (Dugbo Primary School, Obidugbo; latitude $06^{0} 03^{1} 23.58^{11} \mathrm{~N}$, longitude $06^{0} 18^{1} 29.18^{11} \mathrm{E}$ ) consists of seven layers with resistivity values that ranged from 398 to $75000 \Omega \mathrm{m}$ and depth ranged from 0.8 to $162 \mathrm{~m}$. The altitude of this location $88 \mathrm{~m}$. The deduced lithologies include: lateritic top soil for the first layer; fine grained sand for the second layer; fine to medium grained sand for the third layer; medium grained sand for the fourth layer; medium coarse grained sand for the fifth layer; coarse/gravelly sand for the sixth layer and coarse grained sand for the seventh layer. The aquiferous unit delineated lies within the third layer (first aquifer) with resistivity of $288 \Omega$ m,depth and thickness of $7.5 \mathrm{~m}$ and $5.0 \mathrm{~m}$ respectively and also in the fifth layer (second aquifer) with resistivity of $11000 \Omega \mathrm{m}$ and depth of $162 \mathrm{~m}$.

VES 14 location (Along Obi-Iduhon/Obidugbo road, Obidugbo; latitude $06^{0} 03^{1} 39.19^{11} \mathrm{~N}$; longitude $06^{0} 19^{1} 23.57^{11} \mathrm{E}$ ) is made up of seven layers with resistivity values that ranged from 156 to $46800 \Omega \mathrm{m}$ and depth range from 0.8 to $92.5 \mathrm{~m}$. This location has an altitude of $95 \mathrm{~m}$. The deduced lithologies include: lateritic top soil for the first layer, fine-medium grained sand for the second layer; medium- coarse grained sand for the third and the fourth layers respectively; coarse grained sand for the fifth layer; coarse/gravelly sand for the sixth layer and gravelly sand for the seventh layer. The potential aquiferous unit delineated lies within the fourth layer with resistivity of $1120 \Omega \mathrm{m}$,depth and thickness of $31.7 \mathrm{~m}$ and $13.3 \mathrm{~m}$ respectively.

Thus the interpreted geoelectric data correlates with the litho-logic $\log$ (Figure 4) of borehole drilled to a depth of $30.1 \mathrm{~m}$ at Ejeme - Aniogor close to VES 1 (DSMWR, 2010).

Conclusion: The geoelectric investigation for groundwater prospect, carried out in Ejeme - Aniogor and Environs in Aniocha - South Local Government Area of Delta State, Nigeria, has provided some insights into the hydrogeology of the area. Based on the main findings of this study, it can be concluded that the aquiferous units in the study area were mostly confined and the results obtained from the study area were found to be consistent with the lithologic log obtained from borehole drilled in the area. Moreso, a generalized depth to the water table could not be deduced for the area because it varied from one locality to another. Hence, the findings showed that the area has good prospects for groundwater development. There is therefore the need to carry out a geoelectric investigation in any locality prior to sinking a borehole in order to forestall loses and to have productive wells.

\section{REFERENCES}

Allen, JRL (1965). Late Quaternary Niger Delta and Adjacent Area.AAPG Bulletin.49(5): 547 - 600 
Burke, K; Dessauvagie, TJF; Whiteman, AJ (1972). General History of Benue Valley and Adjacent Areas in: Dessauvagie, TJF, Whiteman, AJ (Eds). African Geology University Press, Ibadan. $206-218$

Chinyem, FI (2013). Hydro-geophysical Investigation of Asaba Area, Delta State, Nigeria.Indian Journal of Science and Technology.6(5): 4453 4458

DSMWR, (2010). Delta State Ministry of Water Resources Borehole Lithologic Log, Asaba

Freeborn, OE (2006). Geo - electric Investigation for Groundwater in Aniocha South Local Government Area, Delta State, Nigeria. Global Journal of Geological Sciences 4(2): 209 - 219

Goki, NG (2011). Groundwater Monitoring to determine Vulnerability to Man - made and Natural Pollutants in the Basement Complex.2Hydro-views 2(1): $89-100$

Murat, RC (1970). Stratigraphy and Paeogeography of the Cretaceous and Lower Tertiary in Southwestern Nigeria, In: Dessauvagie, TJF; Whiteman, AJ (Eds). African Geology, University Press, Ibadan, 251 - 266
Obioha, YE; Nwachukwu, MA (2007). Geologic Problems of Groundwater Development: A case study of Nkwerre and Nwangele Areas in Imo state, Southeastern Nigeria. Water Resources.17: $61-69$

Olasehinde, PI (2011). Appropriate Geo - exploration Techniques for Groundwater Exploration in Nigeria Basement.Hydro-views.2(1): 67 - 80

Palacky, GJ; Ritsema, IL; De Jong, SI (1981).Electromagnetic Prospecting for groundwater in Precambrian Terrains in the Republic of Upper Volta. Geophysical Prospecting.29: $932-935$

Reyment, RA (1965). Aspects of the Geology of Nigeria. University Press, Ibadan, 145

Schlumberger Services (1986). Schlumberger Log Interpretation Services Manual, 145

Short, KC; Stauble, AJ (1967).Outline of Geology of Niger Delta.AAPG Bulletin.51: 761 - 799

Zohdy, AAR (1965). The Auxiliary Point Method of Electrical Sounding Interpretation and its Relationship to Dar Zarrouk Parameters.Geophysics.30: $644-650$ 